\title{
Splenic Artery Tortuosity Index on Abdominal CT Scan: Correlation with Age, Sex, BMI and Abdominal Cavity Diameters
}

\author{
Índice de Tortuosidad de la Arteria Esplénica en TC Abdominal: Correlación \\ con la Edad, el Sexo, el IMC y los Diámetros de la Cavidad Abdominal
}

Jehad Fataftah'; Zaid Manasrah²; Raed Tayyem³; Haitham Qandeel³;

Mamoon Al-Omari ${ }^{4}$; Amjad Shatarat ${ }^{5}$ \& Darwish Badran ${ }^{5}$

FATAFTAH, J.; MANASRAH, Z.; TAYYEM, R.; QANDEEL, H.; AL-OMARI, M.; SHATARAT, A. \& BADRAN, D. Splenic artery tortuosity index on abdominal CT scan: correlation with age, sex, BMI and abdominal cavity diameters. Int. J. Morphol., 38(1):17$22,2020$.

SUMMARY: Thorough knowledge of splenic artery course and morphology may help clinician to provide better practice. This Study aims at finding out if there was a relationship between splenic artery tortuosity index and age, sex, Body Mass Index (BMI) and abdominal cavity diameters. Routine abdominal Computerized Tomography (CT) scan images were retrospectively analyzed for 219 patients. Splenic artery tortuosity index was calculated. Abdominal cavity diameters were measured. Age, sex, and BMI were recorded. Splenic artery straight length (x) mean was $9.41 \mathrm{~cm}$ (SD 1.33). Splenic artery tortuous length mean was 15.15 cm (SD 3.31). Splenic artery tortuosity index mean was 1.63 (SD 0.36). Pearson correlation coefficient for Splenic artery tortuosity index vs. age was: 0.02 (P value 0.80 ). Splenic artery tortuosity index for females vs. males were 1.70 vs. 1.57 (P value 0.01 ). Pearson correlation coefficient for Splenic artery tortuosity index vs. BMI was 0.02 (P value 0.75 ). Pearson correlation coefficient for Splenic artery tortuosity index vs. abdominal cavity diameters were: Anterior-Posterior (AP) diameter -0.01 (P value 0.88) and transverse diameter 0.00 (P value 0.98 ). There may be a relationship between splenic artery tortuosity and female sex, but not with age, BMI and abdominal cavity diameters (AP and Transverse).

KEY WORDS: Splenic artery tortuosity index; Sex; Age; BMI; Abdominal cavity diameters.

\section{INTRODUCTION}

The celiac trunk tri-furcate into hepatic, left gastric and splenic arteries. Julius Caesar Arantius of Vienna was the first to give an emphasis of the tortuosity of splenic artery "arteriae lienis, ductum obliquum ac flexuosum, anguis in modum" which described the splenic artery as an oblique bending duct in the form of a snake (Sylvester et al., 1995). the splenic artery is considered the most tortuous vessel in the body (Standring et al., 2008). Thorough knowledge of splenic artery its course and morphology may provide the radiologist with better insight for interpreting abdominal radiology images and safer approaches for radiological interventions. It could also help surgeon plan for better surgical procedures involving the spleen (Bhivate Varsha et al., 2014).
The manner of development of splenic artery tortuosity is believed to be complex. In infancy and childhood, the splenic artery is stretched along its entire course. However the difference in the vessel length and the distance between its origin and splenic hilum contribute to its tortuosity. It was observed that the proximal part of the artery was more tortuous than the distal part (Golder, 2008).

Michels (1995) had a similar conclusion; he found that the tortuosity increases as people get older. The artery is being straight in infants and children, minimally tortuous in middle aged, and markedly tortuous in elderly. $\mathrm{He}$ suggested that the tortuosity of splenic artery enables the motion of the spleen and allows expansion of the stomach

\footnotetext{
${ }^{1}$ Department of Radiology, Faculty of Medicine, Hashemite University, Jordan.

${ }^{2}$ Department of Radiology, Prince Hamza Hospital, Jordan.

${ }^{3}$ Department of General Surgery, Hashemite University, Jordan.

${ }^{4}$ Department of Radiology, Jordan University of Science and Technology, Jordan.

${ }^{5}$ Department of Anatomy, The University of Jordan, Amman, Jordan.
} 
without obstructing blood flow within the splenic artery as passing through the stomach bed (Michels; Daisy Sahni et al., 2003).

Michels (1942) suggested a number of explanations to the tortuosity of splenic artery:

1) Movement of the spleen with respiration and the ability of artery to stretch.

2) Damping system to provide protection the splenic structure.

3) Growth of an artery tethered by its pancreatic branches.

4) Developmental (genetically determined) (Michels).

Literature defined a tortuosity index as a quantitative index to measure tortuosity of blood vessels regardless of image magnification and sampling frequency. This definition was used by researchers to study splenic artery on humans and animals (Dougherty \& Varro, 2000). Variation in mean index of tortuosity between species were noted. Studies on isolated cadaveric splenic arteries found that, the splenic artery was almost straight (very low index of tortuosity) in pigs and dogs and tortuous in the rhesus macaques and baboons (Borley et al., 1995).

Several methods were used to measure splenic artery tortuosity index. One approach is based on abdominal Computerized Tomography (CT) scan images. This study aims at exploring a relationship between the tortuosity index and age, gender, Body Mass Index (BMI) and diameters of the abdominal cavity.

\section{MATERIAL AND METHOD}

Routine abdominal CT scan with intravenous contrast using the arterial phase done between Jan to Dec 2017 were pulled from the hospital electronic archive system. Children were excluded from the study. Patients who suffered from vascular, splenic, hepatic or gastric diseases were excluded from the study. The authors used CT scan images produced via 160 slice Toshiba Aquilion Prime CT scanner.

he straight distance from the origin of the splenic artery, to the point of branching at the hilum of spleen was measured (x). The tortuous course of the splenic artery between these two points was also measured (y) as shown in Figure 1.

Each measurement was repeated three times by different radiologists and an average was then calculated. The index of tortuosity $(\mathrm{y} / \mathrm{x})$ was calculated,

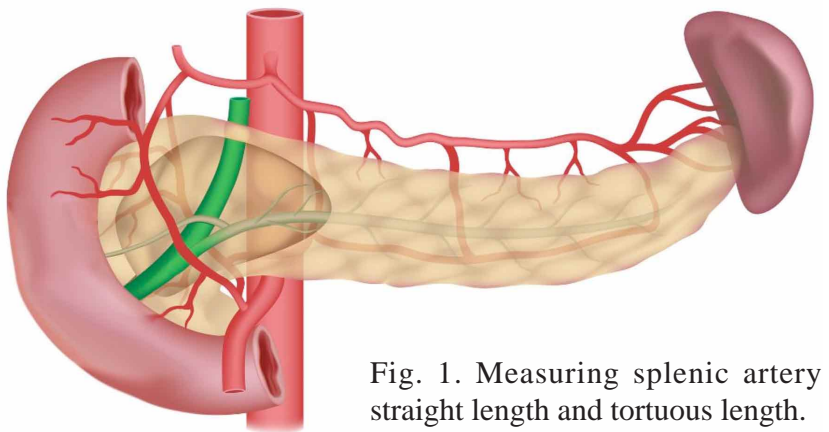

A straight artery would have an index of 1.0. The index would increase as the artery becomes more tortuous.

Diameters of the abdominal cavity at the level of first lumber vertebra were measured transversely and in anterior-posterior plane (AP) as illustrated in Figure 2.

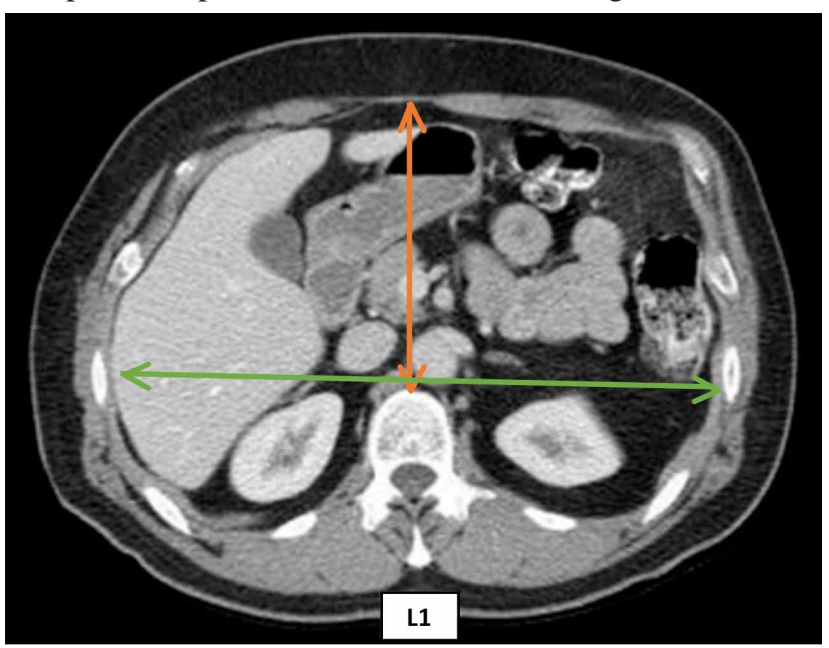

Fig. 2. Measuring abdominal cavity diameters at the level of first lumber vertebra: transverse and anterior-posterior diameter.

The 219 patients met the criteria. Their CT scan images were analyzed. Table I shows patients characteristics.

Data Analysis. Data were collected and saved into Excel Datasheets version 2007. Statistical analysis was performed using Statistical Package for Social Scientists (SPSS) version 17.

Independent-samples t-test was used to evaluate the scores of two different (independent) groups of people (e.g. males and females) and measure the likelihood that an observed difference between data was due to chance. Analysis of Covariance (ANCOVA) was used to statistically control for the possible effects of an additional confounding variable (covariate). Pearson correlation coefficient was used to measure correlation between data. Pearson's chi squared test was used to compare categorical data. $\mathrm{P}$ value $\leq 0.05$ was considered statistically significant. 


\begin{tabular}{ll}
\hline Characteristics of 219 patients included & \\
\hline Males & $114(52 \%)$ \\
Females & $105(48 \%)$ \\
Age & 53 year (range $18-82)$ \\
Splenic artery straight length & $9.41 \mathrm{~cm}(\mathrm{SD} 1.33)$ \\
Splenic artery tortuous length & $15.15 \mathrm{~cm}(\mathrm{SD} 3.31)$ \\
Splenic artery tortuosity index & 1.63 (SD 0.36) \\
Patients with Splenic artery tortuosity index $=1$ & 7 patients (3\%) \\
Pearson correlation coefficient & \\
Splenic artery tortuosity index vs. Age & 0.02 (P value 0.80$)$ \\
Splenic artery tortuosity index vs. Gender & \\
Females vs. males & 1.70 vs. 1.57 \\
Independent samples T test & P value 0.01 \\
ANCOVA - control effect of the covariate BMI & P value 0.01 \\
Splenic artery tortuosity index vs. BMI & 0.02 (P value 0.75$)$ \\
Splenic artery tortuosity index vs. abdominal diameters & \\
Anterior-Posterior (AP) diameter & -0.01 (P value 0.88) \\
Transverse diameter & 0.00 (P value 0.98) \\
\hline
\end{tabular}

\section{RESULTS}

Splenic artery straight length (x) mean was 9.41 $\mathrm{cm}$ (SD 1.33). Splenic artery tortuous length mean was $15.15 \mathrm{~cm}$ (SD 3.31). Splenic artery tortuosity index mean was 1.63 (SD 0.36).

Splenic artery straight length was then grouped into $0.5 \mathrm{~cm}$ intervals. There was no correlation between the average splenic artery tortuosity index for each group and the straight length. There was also no correlation between Splenic artery tortuosity index and age. Pearson correlation coefficient was 0.02 ( $\mathrm{P}$ value 0.80$)$.
The Figure 3 shows that females had higher tortuosity of the splenic artery with an index average of 1.70 compared to 1.57 for males ( $\mathrm{T}$ student test $\mathrm{P}$ value 0.01$)$. However, females also had higher BMI of 29.4 compared to BMI of 27.5 for males as shown in Figure 4 (T student test $\mathrm{P}$ value 0.02 ). ANCOVA was used to statistically remove the effect of the covariate (BMI) which may have an effect on the impact of the independent variable (gender) on the dependent variable (splenic artery index). ANCOVA showed that it was the gender that is causing all the influence on the splenic artery index ( $\mathrm{P}$ value 0.01$)$.

Patients were grouped into 6 groups according to their BMI (underweight, normal, overweight, obesity, severe obesity and morbidly obese). Figure 5 shows that BMI groups were not correlated to splenic artery index. Pearson correlation coefficient was 0.02 (P value 0.75 ).

The length of abdominal cavity AP and transverse diameters were grouped by $3 \mathrm{~cm}$ intervals. Splenic artery index was not affect by the abdominal cavity diameter as shown in Figures 6 and 7. Pearson correlation coefficient for AP diameter was -0.01 (P value 0.88) and Pearson correlation coefficient for transverse diameter was $0.00(\mathrm{P}$ value 0.98 ).

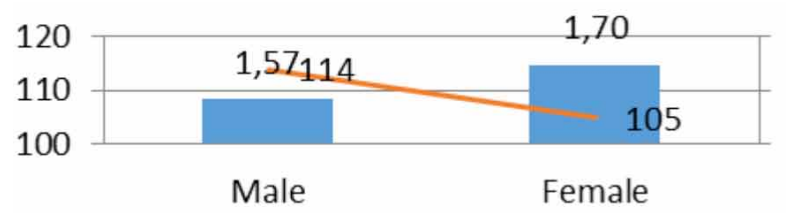

1,80

1,60

1,40

Fig. 3. Correlation of splenic artery tortuosity index with sex.

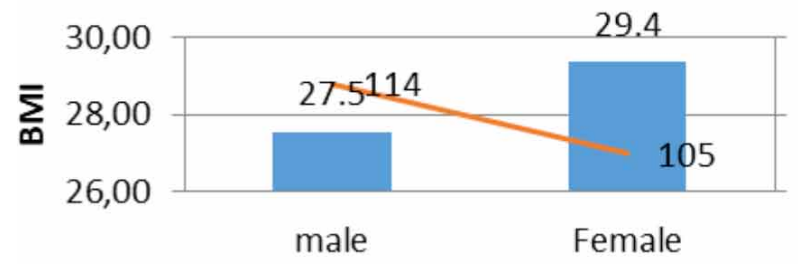

Fig. 4. Correlation of BMI with sex.

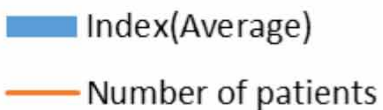




\section{BMI v.s index}

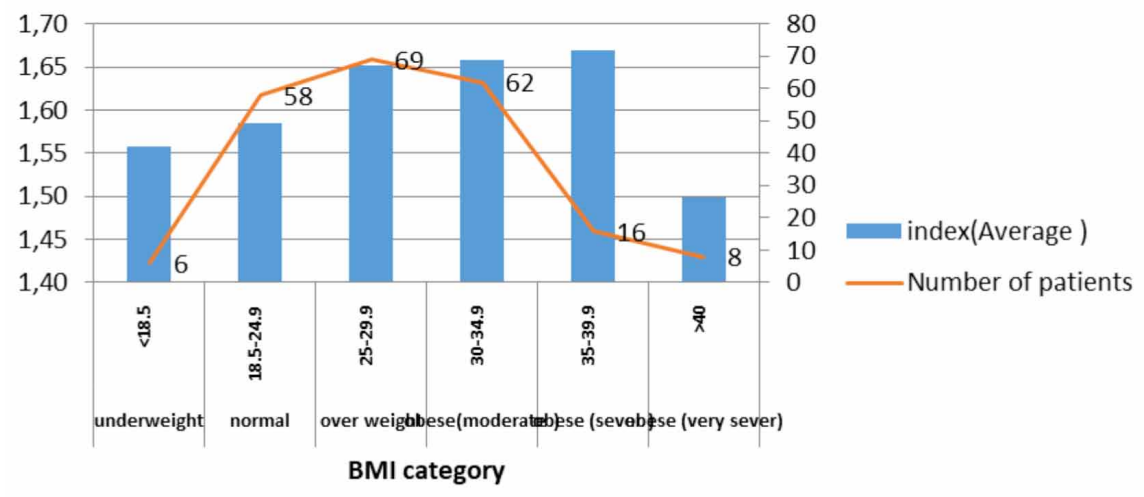

Fig. 5. Correlation of splenic artery tortuosity index with BMI.

\section{AP diameter vs. index}

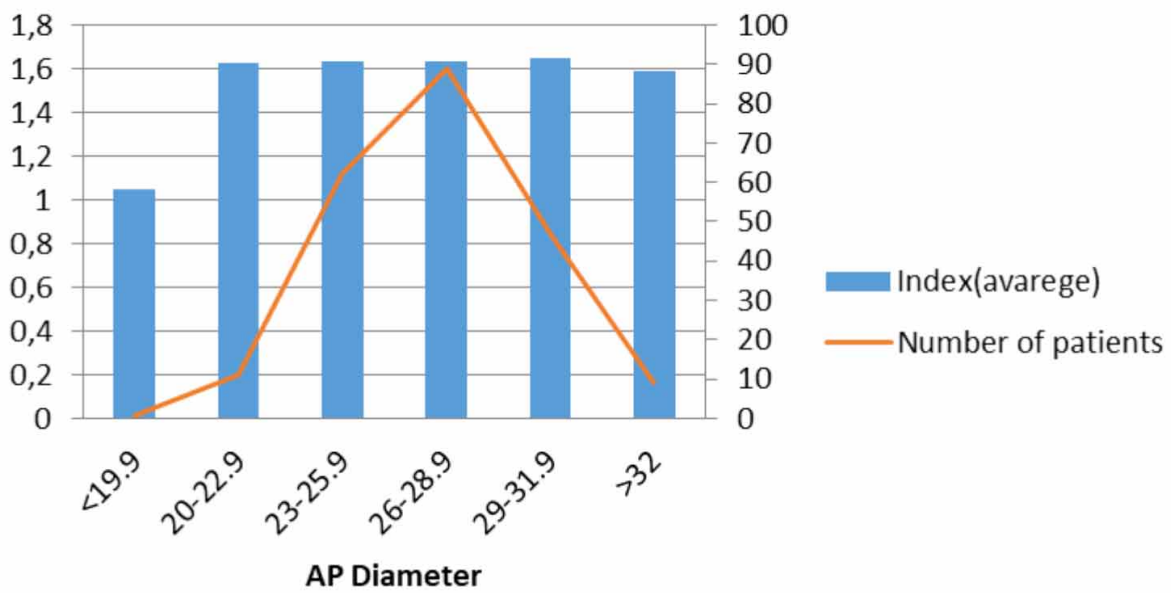

Fig. 6. Correlation of splenic artery tortuosity index with anterior-posterior abdominal cavity diameter (AP).

\section{AP diameter vs. index}

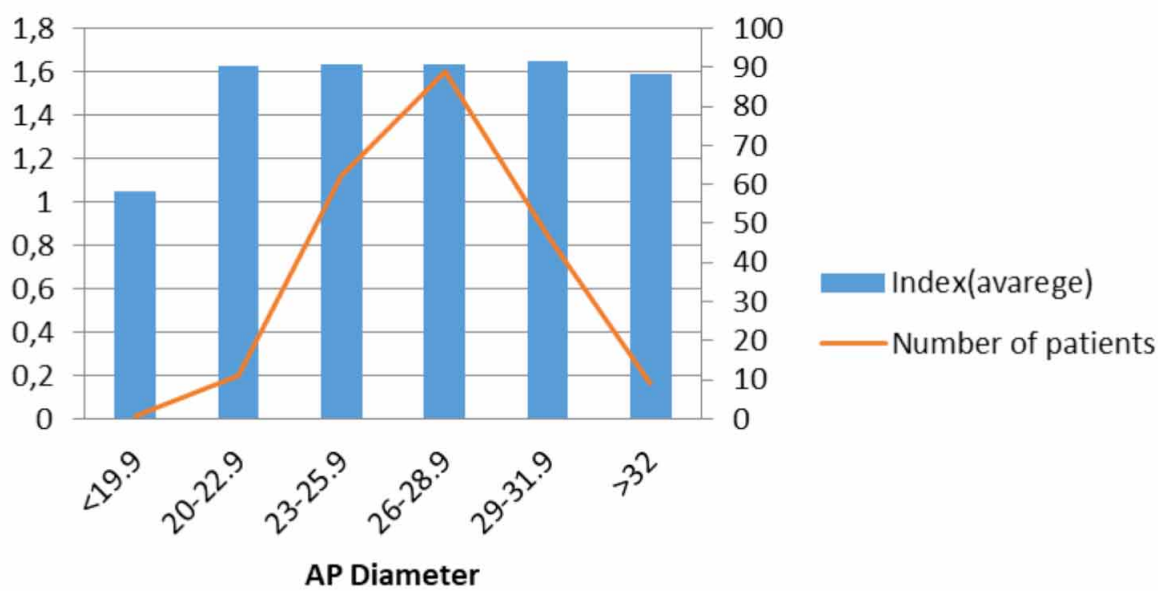

Fig. 7. Correlation of splenic artery tortuosity index with transverse abdominal cavity diameter. 
FATAFTAH, J.; MANASRAH, Z.; TAYYEM, R.; QANDEEL, H.; AL-OMARI, M.; SHATARAT, A. \& BADRAN, D. Splenic artery tortuosity index on abdominal CT scan: correlation with age, sex, BMI and abdominal cavity diameters. Int. J. Morphol., 38(1):17-22, 2020.

\section{DISCUSSION}

The mean length of straight course of splenic artery in this study was $9.41 \mathrm{~cm}$ (SD 1.33) compared to a tortuous course mean of $15.15 \mathrm{~cm}$ (SD 3.31). Other studies reported average straight lengths from $9.52 \mathrm{~cm}$ to $13 \mathrm{~cm}$. While a tortuous course was measured in a range from $12.76 \mathrm{~cm}$ to $17.3 \mathrm{~cm}$ (Abrams \& Meyerovitz, 1997; Jauregui, 1999; De Schepper \& Vanhoenacker, 2000; Bhivate Varsha et al.).

A straight course of splenic artery in adults is rare. Our study reported only 7 (3\%) straight non tortuous splenic arteries. Nagajyothi et al. (2015) reported 5 cases out of 50 adult cadavers.

Several theories have been proposed to explain splenic artery tortuosity. One author suggested that the tortuosity of splenic artery was due to atherosclerotic disease (Michels). However, our study showed that only 10 patients $(4.6 \%)$ suffered from early atherosclerotic changes, the remainder of patients had normal non atherosclerotic tortuous vessels.

Other authors tried to relate splenic artery tortuosity to aging process (Michels, 1995; Sylvester et al.; Golder). Nevertheless, our study showed that there was no correlation between age and tortuosity. One study showed that extremely tortuous splenic artery was associated in several cases with a clinical disease pattern that resembled chronic pancreatitis (Sylvester et al.). In our study, all patients with chronic pancreatitis were excluded from study.

In addition, this study showed that there was no correlation between the splenic artery tortuosity and BMI and abdominal cavity diameter. The authors decided to measure abdominal cavity diameters and not the whole abdominal diameter as abdominal cavity diameters may be more related to visceral fat (intra-abdominal), while the whole abdominal diameter is more related to whole body fat which is indicated by BMI.

The only positive correlation proved in this study was the association of female gender with tortuous arteries. Previous studies showed that infants and children have non tortuous vessels and tortuosity start to develop as people become adults (Michels, 1995; Golder). Authors of this study postulate that the splenic artery may be influenced by female sex hormones leading to more pronounced tortuous vasculature in females. Indirect evidence of this theory stems from the observation that women are more prone to varicose veins probably due to progesterone hormone. However, further studies are needed to prove this hypothesis (London \& Nash, 2000).

\section{CONCLUSION}

Our data suggested that there may be a relationship between splenic artery tortuosity and female gender but not with age, BMI or abdominal cavity diameters (AP, Transverse). This relationship may be due to female sex hormones.

FATAFTAH, J.; MANASRAH, Z.; TAYYEM, R.; QANDEEL, H.; AL-OMARI, M.; SHATARAT, A. \& BADRAN, D. Índice de tortuosidad de la arteria esplénica en TC abdominal: correlación con la edad, el sexo, el IMC y los diámetros de la cavidad abdominal. Int. J. Morphol., 38(1):17-22, 2020.

RESUMEN: El conocimiento del curso y la morfología de la arteria esplénica puede ayudar al médico a proporcionar un diagnóstico y tratamiento oportuno al paciente. Este estudio tuvo como objetivo determinar si existe una relación entre el índice de tortuosidad de la arteria esplénica y la edad, el sexo, el índice de masa corporal (IMC) y los diámetros de la cavidad abdominal. Se tomaron imágenes retrospectivas, de rutina, de 219 pacientes de tomografía computarizada (TC) abdominal. Se calculó el índice de tortuosidad de la arteria esplénica. Se midieron los diámetros de la cavidad abdominal y se registró la edad, sexo y el IMC. La media de la longitud recta de la arteria esplénica (x) fue de $9,41 \mathrm{~cm}$ (DE 1,33). La longitud tortuosa de la arteria esplénica fue de 15,15 $\mathrm{cm}$ (DE 3,31). La media del índice de tortuosidad de la arteria esplénica fue de 1,63 (DE 0,36). El coeficiente de correlación de Pearson para el índice de tortuosidad de la arteria esplénica vs. edad fue: 0,02 (valor de P 0,80). El índice de tortuosidad de la arteria esplénica para las mujeres frente a los hombres fue de 1,70 frente a 1,57 (valor de P 0,01). El coeficiente de correlación de Pearson para el índice de tortuosidad de la arteria esplénica versus el IMC fue de 0,02 (valor de P 0,75). El coeficiente de correlación de Pearson para el índice de tortuosidad de la arteria esplénica frente a los diámetros de la cavidad abdominal fue: diámetro anterior-posterior (AP) -0,01 (valor $\mathrm{P} 0,88$ ) y diámetro transversal 0,00 (valor P 0,98). Puede existir una relación entre la tortuosidad de la arteria esplénica y el sexo femenino, sin embargo no se encontró relación con la edad, el IMC y los diámetros de la cavidad abdominal (AP y transversal).

PALABRAS CLAVE: Índice de tortuosidad de la arteria esplénica; Sexo; Edad; IMC; Diámetros de la cavidad abdominal.

\section{REFERENCES}

Abrams, H. \& Meyerovitz. M. Splenic Arteriography. In: Baum, S. (Ed.). Abrams' Angiography. $4^{\text {th }}$ ed. Boston, Little Brown and Company, 1997. pp.1457-95.

Bhivate Varsha, R.; Roshan,S.; Kharate Rahul, P. \& Nivedita, P. Study of diameter, length, tortuosity of splenic artery and its branches with its clinical implications. J. Res. Med. Dent. Sci., 2(4):22-6, 2014. 
FATAFTAH, J.; MANASRAH, Z.; TAYYEM, R.; QANDEEL, H.; AL-OMARI, M.; SHATARAT, A. \& BADRAN, D. Splenic artery tortuosity index on abdominal CT scan: correlation with age, sex, BMI and abdominal cavity diameters. Int. J. Morphol., 38(1):17-22, 2020.

Borley, N. R.; McFarlane, J. M. \& Ellis, H. A comparative study of the tortuosity of the splenic artery. Clin. Anat., 8(3):219-21, 1995.

Daisy Sahni, A.; Indar Jit, B.; Gupta, C. N.; Gupta, D. M. \& Harjeet, E. Branches of the splenic artery and splenic arterial segments. Clin. Anat., 16(5):371-7, 2003.

De Schepper, A. \& Vanhoenacker, F. Medical Imaging of the Spleen. Berlin, Springer-Verlag, 2000. pp.7-12.

Dougherty, G. \& Varro, J. A quantitative index for the measurement of the tortuosity of blood vessels. Med. Eng. Phys., 22(8):567-74, 2000.

Golder, W. A. Tortuosity and calcification of the splenic artery. More than an additional finding. Radiologe, 48(11):1066-7, 2008.

Jauregui, E. Anatomy of the splenic artery. Rev. Fac. Cienc. Med. Univ. Nac. Cordoba, 56(1):21-41, 1999.

London, N. J. \& Nash, R. ABC of arterial and venous disease. Varicose veins. B. M. J., 320(7246):1391-4, 2000.

Michels, N. A. Blood Supply and Anatomy of the Upper Abdominal Organs. London, Pitman Medical Publishing Co. Ltd., 1995.

Michels, N. A. The variational anatomy of the spleen and splenic artery. Am. J. Anat., 70(1):21-72, 1942.

Nagajyothi, D.; Sreelatha, S.; Saritha, S.; Ramani, T. V.; Anjum, A. \& Yesender, M. Study of variations in origin and course of splenic artery in the 50 adult human cadavers. Int. J. Med. Sci. Clin. Invent., 2(7):111420, 2015.

Standring, S.; Borley, N. \& Healy, J. Abdomen and Pelvis. In: Standring, S. (Ed.). Gray's Anatomy. The Anatomical Basis of Clinical Practice. $40^{\text {th }}$ ed. Edinburgh, Churchill Livingstone/Elsevier, 2008.

Sylvester, P. A.; Stewart, R. \& Ellis, H. Tortuosity of the human splenic artery. Clin. Anat., 8(3):214-8, 1995.
Corresponding author:

Dr Raed Tayyem

Department of General Surgery

Hashemite University

JORDAN

Email: rtayyem@yahoo.com

Received: 17-07-2019

Accepted: 22-08-2019 